\title{
協同組合による中山間地域の買い物弱者支援の課題と展開方向
}

\author{
武田彬奈（岡山大学大学院環境学研究科） \\ 小松 泰信（岡山大学） \\ 横溝功 (岡山大学)
}

\section{Development of Support System by Cooperatives for People at a Disadvantage in Shopping in Hilly and Mountainous Areas}

\author{
Akina Taketa (Graduate School of Environmental Science,Okayama University) \\ Yasunobu Komatsu (Okayama University) \\ Isao Yokomizo (Okayama University)
}

In several residential areas, people are facing problems in shopping owing to the lack of means of transportation and facilities.

However, hilly and mountainous areas in which many elderly residents with the disadvantage of shopping are holding subjects, such as the continuity of a support business.

This report focused on cooperatives whose associates share a responsibility in continuing business ventures.

\section{1. 課題と方法}

近年, 交通手段の欠如や，居住地の商業機能の低 下が原因で，日常の買い物に困難を抱兄る「買い物 弱者」の増加が問題視されている. 本報告では，(1) 招かやまコープの個配事業，打上び(2) JA 広島市の

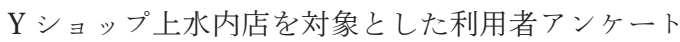
調査などによる実態調查を行い，その結果をもとに 買い物弱者支援の現状と課題を明らかにし, 協同組 合による中山間地域での長期的な買い物弱者支援の 展開方向を示す.

\section{2. 買い物弱者支援対策の方法と課題}

（1）買い物弱者支援対策の方法

経済産業省によると，買い物弱者支援の方法は以 下の三つにまとめられる ${ }^{1}$.

第 1 に, JA の生活店舗展開, コンビニエンスス トア・スーパーマーケットの設置などにより，「消 費者の身近な場所に店を作る」ことである．この方 法は，利用者自ら買い物できる点が特徴である.
The present condition of the people at a disadvantage in shopping in hilly and mountainous areas was clarified by a survey. The questionnaires were distributed to the customers of the individual doorto-door delivery business of Okayama Copland, and the users of the Y-shop, Kamiminochi branch of JA Hiroshima City. Further, the survey results indicated that cooperatives are engaging in the development of long-term support for people at a disadvantage in shopping in hilly and mountainous areas.

第 2 亿, ネットスーパー, 通信販売, 移動販売, 夕食・弁当宅配による移動コストの軽減，すなわち 「消費者の家まで商品を届ける」方法である.

第 3 に，デマンドタクシー・コミュニティバスの 運行, 福祉有償運送, 買い物ツアーの実施による「家 から出かける手段の提供」があげられる．買い物弱 者とされる，あるいはそのリスクを抱える人々の多 くは，高齢者であり，自家用車を所有していない， または運転免許を返納していることが考兄られる. 居住地が中山間地域であれば，商業施設が少なく公 共交通サービスが不十分であるケースも多い，その ために, この方法は買い物以外にも通院や公共施設 利用などを目的とした外出にも応用が可能である。

以上のように，買い物への物理的アクセスの改善 が高龄者の自立度維持にもつながるのである ${ }^{2)}$.

\section{（2）買い物弱者支援対策の課題}

買い物弱者支援対策の課題として，以下の 3 点が あげられる。

(1)二ーズの把握の必要性 : 地域, 年代, ライフスタ 
イル，経済状沉，健康状態など，買い物弱者化の要因 は様々であり，買い物弱者とされる人々のニーズを把 握しなければならない，乙かしながら，それには大規 模な調査が必要であり，また支援対策の運営主体に向 けてその結果が発信されなければならない。

(2)各地域に適した支援対策の必要性 : 各地域で求 められる対策も異なるため, 「適切な支援対策」を 行らために，地域の実態把握が不可欠である.

(3)支援対策事業の継続性 : 買い物弱者を抱元る地域 では商業機能が低下しているケースが多く, 支援対策 事業の収益性も低くなりがちである. 事業が長期的に 行われなければ買い物弱者問題の解消にはならず，収 益の見込める仕組みづくり，ならびに地域住民による 事業利用への理解を促すことが必要である.

これらを克服しらる支援主体として考兄られるの が, 協同組合である. 協同組合には, (1)組合員への 奉仕を第一とした事業を行う, (2)組合員が組合運営 に日常的に参画することが原則であり, 事業の継続 に関し責任が生じる, (3)参画に扣いて, 買い物弱者 とされる人々の意見を事業に反映させることが可能 である，などの特徵がある。

次節より, 生活協同組合, 農業協同組合の買い物 弱者支援対策の概要をまとめるとともに中山間地域 に扮沙る利用状沉を分析し, 買い物弱者支援の展開 方向について考察する.

\section{3. おかやまコープによる「個配事業」}

\section{(1) 組織・事業概要}

岡山県を区域として活動する生活協同組合「扔か やまコープ」は 1956 年に設立され，2010 年 3 月末 時点の組合員数は 307,892 名である.

組合員に取扱商品を提供する方法は, 店舗での販 売とカタログ打よびインターネット利用の宅配の二 つに大別される。宅配事業には，(1)利用者が店舗へ 出かける必要が無く, 移動コストが削減される, (2) 毎週決まった曜日に商品が届き, 在宅していない場 合でも対応が可能でライフスタイルが買い物に左右 されない, (3)班配の仕分け, 個配の受取りがコミュ ニケーションの機会となる, (4)カタログによる注文 により, 食料品から雑貨まで, 多様な商品を自ら選 択し購入できる, (5)店舗と比較し物件費や人手がか からないため, 中山間地域での展開が可能, といっ た特徵があり，買い物弱者支援に適している.
宅配事業はさらに, 利用者の自宅まで商品が届き， 月 840 円（1 か月の購入額が 4 万円を超える，ある いは要介護認定などの条件を満たす利用者は 420 円）の利用料を支払う「個配」，5人以上の集合場 所に商品が届く「班配」, 利用者の指定した店舗に 商品が届く「拠点配」の 3 種類に分けられる. らち, もっとも組合員のニーズに柔軟に対応可能であると 考えられる「個配」について，地域ごとの利用状況 を比較する.

\section{（2）岡山県・岡山市・高梁市における利用状況}

岡山県は面積の $75 \%, 27$ 市町村中 22 市町村が中 山間地域である。調査対象とした高梁市は, 2010 年度時点の高齢化率が 34.6\%（7 位/27 市町村）と 高い水準にある，高齢化率 40\%を超える集落が注 とんぞであり，60\%を超える集落も存在する．国勢

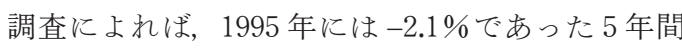
の人口増減率が， 2010 年には $-9.9 \%$ になったりり, 人口流出も著しい地域である。この高梁市を中山間 地域と位置付け，一方で北部を除いた大半が中山間 地域に含まれず，2010 年時点の高齢化率が $21.7 \%$ と最も低い岡山市（27 位/27市町村）を都市部と位 置付忷, 岡山県全域との個配利用状況を比較する.

3 地域について, 年度別の利用高, 利用者数の推 移を示したものが表 1 である. 数值の推移をみると, 他地域と比較して高梁市が大きな伸びを示している ことがわかる. 岡山市は利用高に減少を示した年度 も, 高梁市は伸び続けている.

\section{表 1. 岡山県, 岡山市, 高梁市の個配利用高, 利用 者数の年度別推移}

\begin{tabular}{l|r|r|r|r|r|r}
\hline \hline \multirow{2}{*}{ 岡山県 } & $\begin{array}{c}\text { 利用高 } \\
\text { (万円) }\end{array}$ & 18,164 & 19,423 & 19,147 & 22,069 & 19,299 \\
\hline $\begin{array}{c}\text { 利用者数 } \\
\text { (人) }\end{array}$ & 30,559 & 33,931 & 36,100 & 38,402 & 40,556 \\
\hline 岡山市 & $\begin{array}{c}\text { 利用高 } \\
\text { (万円) }\end{array}$ & 7,755 & 8,274 & 7,993 & 9,134 & 7,783 \\
\hline $\begin{array}{c}\text { 利用者数 } \\
\text { (人) }\end{array}$ & 12,771 & 13,918 & 14,575 & 14,950 & 15,468 \\
\hline 高梁市 & $\begin{array}{c}\text { 利用高 } \\
\text { (万円) }\end{array}$ & 233 & 274 & 288 & 353 & 388 \\
\hline $\begin{array}{c}\text { 利用者数 } \\
\text { (人) }\end{array}$ & 401 & 474 & 571 & 755 & 911 \\
\hline
\end{tabular}

資料：抎かやまコープ内部資料より筆者作成 


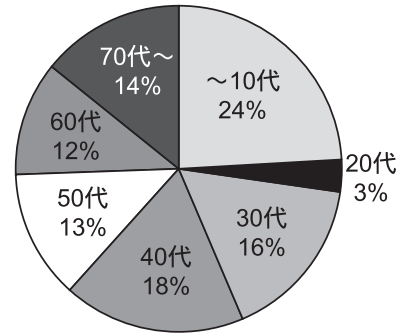

岡山市

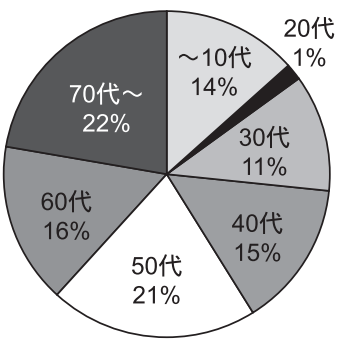

高梁市

図 1. 2010 年度年代別個配利用者構成

資料: 表 1 に同じ

また，年代別の利用者数について岡山市と高梁市 を比較したものが図 1 である.

岡山市では 30 代，40 代が占める割合が大きいの に対し，高梁市では 60 代，70 代以降の高齢者の占 める割合が大きい。

以上の比較より，中山間地域では，個配に対する 需要が高まる傾向にあり，その多くに高歯者が含ま れることがわかる。よって，执かやまコープでは， 高歯者に，より利用しやすいサービスを提供するこ とが求められているといえる.

次節で, 高梁市の個配利用者アンケート結果を分 析し, 個配が買い物弱者解消に貢献する可能性につ いて考察する.

\section{（3）おかやまコープ個配利用者アンケート調査}

扣かやまコープ個配利用者の, 当該事業利用状況 を把握することを目的とし, 高梁市の個配利用者 20 名を対象としたアンケート調査を行った. 調査 期間は 2011 年 9 月 25 日〜 10 月 6 日，商品配達時 に用紙を配布し, 回答後郵送にて回収した. 回収率 は85\%であった。

回答者は全員女性, 平均年齢は 67.1 歳であった. 主な購入品目は, 生鮮食品では肉類, 魚類が多く, 一方で野菜は自ら栽培しているケースが多く, 回答 数は少なかった. また, 重いために運搬に労力を要
表 2. 個配の利用品目（複数回答, $n=108$, 回答者 数 17)

\begin{tabular}{|c|c|c|c|c|c|c|c|c|c|c|}
\hline 品目 & $\begin{array}{l}\text { 冷 } \\
\text { 凍 } \\
\text { 食 } \\
\text { 品 }\end{array}$ & $\begin{array}{l}\text { 㮅 } \\
\text { 算 }\end{array}$ & $\begin{array}{l}\text { 調 } \\
\text { 味 } \\
\text { 料 }\end{array}$ & $\begin{array}{l}\text { 肉 } \\
\text { 類 }\end{array}$ & $\begin{array}{l}\text { 魚 } \\
\text { 類 }\end{array}$ & $\begin{array}{l}\text { 果 } \\
\text { 物 }\end{array}$ & $\begin{array}{l}\text { 菓 } \\
\text { 類 }\end{array}$ & 卵 & $\begin{array}{l}\text { 野 } \\
\text { 采 }\end{array}$ & $\begin{array}{l}\text { 飲 } \\
\text { 料 }\end{array}$ \\
\hline $\begin{array}{c}\text { 回答数 } \\
\text { (人) }\end{array}$ & 17 & 16 & 14 & 14 & 12 & 10 & 10 & 9 & 7 & 6 \\
\hline
\end{tabular}

資料：アンケート調査より筆者作成

する冷凍食品, 多様な店舗利用が必要とされる雑貨 の利用が多い，

個配を利用した感想については, 肯定的なものに, 「留守でも商品を届けてくれるので助かる」，「配達 スタッフにとてもよくしてもらって拈り，今の内容 で満足している」，「重いものを運ぶ負担がなくなっ た」なぞがあがる。一方で改善すべき点や要望につ いては，「月額利用料が負担になって和り，いつま で利用を継続できるかわからない,「宅配だけでは, 急に必要なものがあっても揃わないので, 移動販売 も行って欲しい」,「カタログによる注文方法が複雑 なので，利用しづらい」，「要望があっても，遠慮を 感じ職員に伝えられない」などがあげられた。

個配を利用するようになったきっかけで最も多 かったのは,「職員による推進」であった。また,「班 配を利用していた仲間が死亡し, 個配に切り替えた」 といら利用者もおり，高齢化，人口流出が進行した 地域では, 職員による積極的な利用推進が必要とさ れる.

2004 年に合併し高梁市となった旧備中町地区は, 高齢化率が $48.5 \%$ （平成 17 年国勢調査）と高く, 公共交通サービスが十分に行き届いていない，図 2 に示されるように，買い物に不便を感じている利用 者も多い。このように, 買い物弱者の増加が著しい 地域での対応が急がれている.

（4）おかやまコープにおける個配事業の位置づけ

扔かやまコープは, 買い物弱者問題が顕在化する 以前より個配事業に取り組んでいるが，近年「買い 物弱者支援対策」である点に着目し，高齢者向けの 商品開発などに取り組んでいる。

しかしアンケート結果より，個別宅配を利用する 組合員が遠慮や機会の少なさが原因で，手数料の金 額なぞの要望を職員に伝えられていない実態も明ら かになった. 扔かやまコープでは, インフォメーショ 
表 3. 回答者の年齢, 性別, 居住集落および買い物状況

\begin{tabular}{|c|c|c|c|c|c|c|}
\hline No. & 年齢 & 性別 & 集落 & \begin{tabular}{|l|} 
買い物に不便を \\
感じていますか?
\end{tabular} & 理由 & 生協への意見・要望 \\
\hline (1) & 67 & 女 & 高山 & いいえ & - & $\begin{array}{l}\text { 月額利用料が負担となって敃り，いつまで利用を } \\
\text { 継続できるかわからな. }\end{array}$ \\
\hline (2) & 78 & 女 & 高山 & はい & $\begin{array}{l}\text { ちょっと思いついていける } \\
\text { 近い場所に店がない. }\end{array}$ & - \\
\hline (3) & 68 & 女 & 布賀 & いいえ & 生協でものが揃ら。 & - \\
\hline (4) & 82 & 女 & 布賀 & はい & $\begin{array}{l}\text { 店が遠く, 欲しいものが間 } \\
\text { に合わない. }\end{array}$ & - \\
\hline (5) & 84 & 女 & 平川 & はい & $\begin{array}{l}\text { 近くに店が無い, 交通の便 } \\
\text { が悪い. }\end{array}$ & - \\
\hline (6) & 82 & 女 & 平川 & はい & 店まで 2 時間かかる. & 経済的理由で思うように注文できない. \\
\hline (7) & 74 & 女 & 備中町 & はい & \begin{tabular}{|l|} 
店と家が $10 \mathrm{~km}$ 以上離れていい. \\
るが，車を運転できない. \\
\end{tabular} & - \\
\hline (8) & 59 & 女 & 備中町 & はい & - & - \\
\hline (9) & 63 & 女 & 備中町 & いいえ & $\begin{array}{l}\text { 今のところは車を運転でき } \\
\text { る.しかし将来は心配. }\end{array}$ & 要望があればアンケートに記入する. \\
\hline (10) & 67 & 女 & 地頭 & いいえ & - & 注文用紙の文字が小さい. \\
\hline (11) & 50 & 女 & 川上町 & いいえ & - & 注文用のカタログが見づらい. \\
\hline (12) & 76 & 女 & 吹屋 & いいえ & - & 注文方法が複雑でわかりにくい. \\
\hline (13) & 50 & 女 & 吹屋 & はい & 近くにスーパーが無い. & - \\
\hline (14) & 73 & 女 & 宇治町 & はい & $\begin{array}{l}\text { すぐに必要なものがあって } \\
\text { も買えない. }\end{array}$ & - \\
\hline (15) & 32 & 女 & 宇治町 & いいえ & - & $\begin{array}{l}\text { 手数料が高い. とっさの時に買い物ができるしく } \\
\text { みも欲しいが，遠慮を感じ職員に伝えられない. }\end{array}$ \\
\hline (16) & 87 & 女 & 松山 & いいえ & - & 要望があっても，職員に伝える手段が無い。 \\
\hline (17) & 50 & 女 & - & はい & $\begin{array}{l}\text { 家から近いスーパーは小さ } \\
\text { く品揃えが悪い. }\end{array}$ & - \\
\hline
\end{tabular}

資料 : 表 2 に同じ

注 : 一は未回答

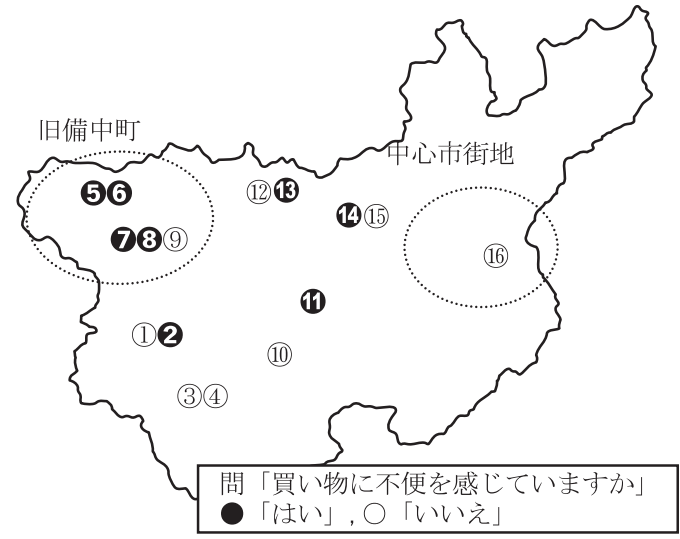

図 2. 回答者の居住地分布

資料 : 表 2 に同じ

ンセンターヘの電話, メールや, アンケート記入に よる意見・要望の収集を行っている. より多くの組
合員の意見を把握するために，これらの手段の利用 を促すことが肝要である.

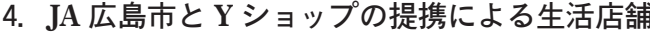 経営}

\section{（1）組織・事業概要}

JA 広島市は 2010 年 3 月時点の組合員数は 93,477 名（正組合員 19,857 名, 准組合員 73,620 名) である. 管内には 54 の店舗がある.

管内では，農業従事者の重要な買い物の場であっ た生活店舗の多くが撤退し，買い物弱者が増加して いた。 また，残された店舗も流通業者の撤退により 「仕入れ弱者」となっていた. そこで，以前よりパン を仕入れていた山崎製パン株式会社のボランタリー

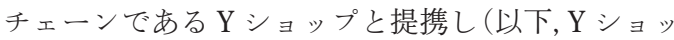
プ化)，仕入先を確保している. 
Y ショップ化による影響には，(1)ヤマザキの全国 物流網, スーパーバイザー機能を活かした商品供給 体制を受けられる，(2)地域や店舖形態に合わせた品 揃え（生産資材，管内産品など JA ならではの品揃 壳が可能), (3) Y ショップの店舗運営支援（販売促 進企画，情報提供など）を受けられる，(4)売上に関 係なく月々定額の運営費で提携が可能，(5)初期投資 に打いて，加盟金，保証金，最低限の固定費のみの 支払いで，ロイヤリティは無い， 6)支所店舗がコン ビニエンスストア化することでオープンな䨌囲気が できた，ことがあげられる。

$\mathrm{Y}$ ショップ上水内店は, JA 広島市による $\mathrm{Y} シ ョ ッ$ プの一号店として，2009年 12 月に開店した. 上水 内は広島市佐伯区の山間部の集落である。2010 年 度時点の商圏人口は半径 $5 \mathrm{~km}$ 以内に 354 世帯で, 定休日 (水曜) を除く $9: 00 \sim 19: 00$ 亿営業して いる. 取扱商品は通常のコンビニエンスストアの品 揃えに加光, 生鮮食品, 生産資材, 衣類など多岐に わたる。利用者とのコミュニケーションを通して得 られた意見や要望を品矢ろ光に反映させている，月 2 回行われる特売をはじめとした情報は, チラシの 配布によって発信されている。毎週月曜日と木曜日 に，電話注文による食料品や生産資材の配達を行っ て抢り, 外出が困難な利用者にも対応している.

\section{（2）中山間地域における利用状況}

$\mathrm{Y} シ ョ ッ フ ゚ 上$ 水内店来店者の, 当該店舗利用状況 ならびに普段の買い物について把握することを目的 に, アンケート調查を行った。調査対象は Y ショッ プ上水内店来店者 78 名中 23 名, 調查時期は 2011 年 9 月 30 日 (金) $9: 30 \sim 19: 00$, 買い物後に聞 き取り調査を行った。回答者の性別は, 男性 7 名

表 4. Y ショップ利用以外の買い物手段（複数回答, $\mathrm{n}=40$, 回答者数 17 )

\begin{tabular}{l|c}
\hline \hline 方法 & 回答者数（人) \\
\hline 他店で買ら & 14 \\
\hline 野菜を自給 & 11 \\
\hline 宅配 & 5 \\
\hline 人からもらら & 5 \\
\hline 移動販売 & 3 \\
\hline 家族に買ってきてもらら & 2 \\
\hline
\end{tabular}

資料：アンケート結果より筆者作成
女性 16 名，平均年齢は 68.2 歳であった.

店舗までの移動手段は徒歩 4 名, 自家用車が 19 名であり, 自家用車の利用の有無が買い物環境を大 きく左右することが示唆された。

当該店舗の利用回数は個人差があったものの, 平 均は週 3 回であった.

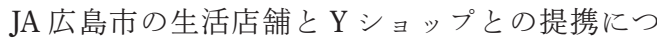
いては,「営業時間が長くなり，仕事帰りにも利用 できるようになった」,「土日も営業するようになっ たので助かる」,「品揃えが改善された」,「店の雲囲 気が明るくなり，利用しやすくなった」といら意見 があげられ，利便性の向上が強調されていた。

当該店舗以外の日用品入手手段もあるが（表 4), 「自分で買い物できるのが楽しい」，「店で知り合い や店員とコミュニケーションがとれる」，「近所には 他に店が無いので，ここがないと困る」という意見 があげられた，以上のように，楽しみの場が提供さ れていることがわかる.

「普段の買い物に不便を感じるか？」の問いに対 する回答は表 5 の通りであった。いずれの年代も買 い物に不便を感じると回答した利用者は少なかった ものの, 当該店舗のほかに利用している店舗は, 上 水内地区から車で約 1 時間かかる場所に位置してい る.よって，現在の買い物環境の維持には「車を自 由に運転できること」が不可欠となる。しかし，高 齢者層はいずれ車の運転が困難になるリスクを抱兄 ているため, 住民による危機感の共有が必要である.

\section{（3）JA 広島市における位置づけと推移}

JA 広島市の購買担当者によれば, JA 広島市は, 生 活店舗を組合員の重要な買い物の場であると認識し ており, 組合員の生活環境の維持を第一義とし，今

\section{表 5. 買い物の不便さに対する回答一Y ショップ上 水内店利用者一（回答者数 21）}

\begin{tabular}{cccc}
\hline \hline \multirow{2}{*}{ 年齢（歳） } & \multicolumn{3}{c}{ 買い物に不便を感じていますか? } \\
\cline { 2 - 4 } & はい & いいえ & 総計 \\
\hline$\sim 59$ & 2 & 1 & 3 \\
\hline $60 \sim 69$ & 1 & 4 & 5 \\
\hline $70 \sim 79$ & 2 & 6 & 8 \\
\hline $80 \sim$ & 1 & 4 & 5 \\
\hline 総計 & 6 & 15 & 21 \\
\hline
\end{tabular}

資料: 表 4 に同じ 
表 6. $Y$ ショップ上水内店の供給目標達成率の推移

\begin{tabular}{c|c|c|c|c|c|c|c|c|c|c|c}
\hline \hline 年月 & '10.10 & '10.11 & '10.12 & '11.01 & '11.02 & '11.03 & '11.04 & '11.05 & '11.06 & '11.07 & '11.08 \\
\hline $\begin{array}{c}\text { 供給目標 } \\
\text { 達成率 (\%) }\end{array}$ & 101.1 & 90.3 & 75.9 & 87.8 & 70.3 & 96.0 & 99.5 & 87.4 & 70.7 & 95.0 & 92.0 \\
\hline
\end{tabular}

資料: JA 広島市 $\mathrm{Y} シ ョ ッ フ ゚$ 上水内店月別効率指標より筆者作成

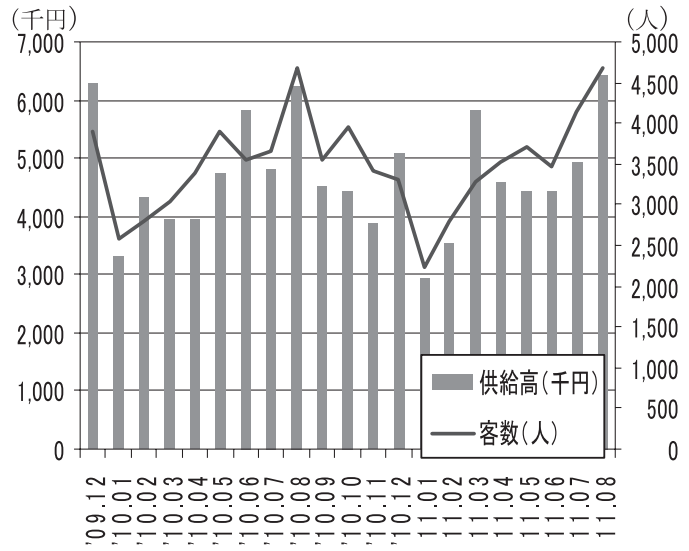

図 3. JA 広島市 $\mathrm{Y}$ ショップ上水内店の売上・来客 数推移

資料：表 6 亿同じ

後も自らの「仕入れ弱者」体質解消のために $\mathrm{Y} シ ョ ッ$ プとの提携店舗を増やす計画である. 売上, 来客数 を開店初年度と今年度で比較する（図 3 参照）と， 季節ごとに同様に推移していることが読み取れる が，赤字を克服できていないとのことであった．し かしながら, 組合員への奉仕のために, 昨年度売上 実績などのデータをもとに供給目標（表 6) を設定 して抢り, 職員のモチベーションの向上と, 収益性 の改善を図っていた.

「民間企業との提携」といら業態を，「協同組合運 営のあり方」としていかに評価すべきであるかは検 討の必要がある. 当事例はJA グループが自らのノウ 八ウで生活店舗事業を存続することの困難性を示唆 している。 しかし，株式会社ではあるが，当JAの意 向や運営手法を尊重し，柔軟な対応を示すYショッ プとの提携によって，組合員の不利益の解消に努め ている点は評価できる。 2011 年度中に管内全 14 店舗 の $\mathrm{Y} シ ョ ッ フ ゚$ 化が完了寸る計画であり, 各店舗を拠 点とした地域ごとの買い物弱者支援が期待される.

\section{5. むすびに}

以上の分析を踏まえ, 協同組合による買い物弱者
支援の展開方向について考察する.

招かやまコープの個配事業では, 利用者のニーズ 把握手段の利用促進によって, JA 広島市の $\mathrm{Y}$ ショッ プ経営では，各生活店舗を拠点とした買い物弱者支 援によって，第 2 章であげた課題(1) ニーズの把握の 必要性，(2)各地域に適した支援対策の必要性，の克 服に向けて動いていた。

しかし，(3)支援事業の継続性については，その判 断に時間を要する点や，収益性の改善が困難である ことから，今後も慎重な検討が必要である.

しかし，民間企業の目的が収益を上げることであ るのに対し，協同組合の目的は組合員への奉仕であ る. 協同組合による買い物弱者支援の継続は，中山 間地域の買い物弱者問題の解消，すなわち組合員へ の奉仕に繋がる．よって，職員と組合員が課題意識 を共有し，積極的な事業への参画を促進することに よる事業の継続が求められる.

注 1）経済産業省 [2]の pp. 2-3 を引用.

2）農林水産政策研究所 [8] の p. 73 を引用.

\section{引用文献・参考文献}

［1］岩間信之「フードデザート問題＼cjkstart無縁社会が 生む『食の砂漠』」農林統計協会, 2011 年.

［2］経済産業省「買い物弱者応援マニュアル ver. $2.0 」 2011$ 年.

［3］杉田聡「買物難民一もらひとつの高齢者問題」 大月書店，2008 年.

［4］高梁地域公共交通会議「高梁地域公共交通総 合連携計画」2010 年.

[5]統計局「平成 17 年度国勢調査」 2006 年.

[6] 統計局「平成 22 年度国勢調査」 2011 年.

[7] 日本生協連会員支援本部「福井発の挑戦一生 協が取り組む経営品質向上と事業ネットワー ク」日本生活協同組合連合会, 2011 年.

[8]農林水産省農林水産政策研究所「食料品アクセ 又問題の現状と対応方向 (中間報告)」2011 年.

（受理日：2012 年 3 月 9 日） 